\title{
O compliance no setor de saúde
}

A preocupação com a conformidade legislativa se mostra cada vez mais frequente em diversos setores, inclusive o setor de saúde. Empresas das áreas hospitalar e farmacêutica, por exemplo, vêm investindo de forma mais frequente em medidas para se adequarem às leis e diretrizes concernentes às suas atividades. Tais providências podem ser consideradas partes de um plano que visa à adequação com as normas regulatórias. Em suma: as empresas do setor de saúde estão se empenhando para adotar programas de compliance.

O termo "compliance" tem sua origem na língua inglesa e significa atuar de acordo com o que foi estabelecido. Essa expressão está sendo bastante utilizada ultimamente no meio empresarial, pois se trata de uma forma de diminuir os riscos existentes no âmbito de uma organização. Dentre os objetivos de um programa de compliance estão: o cumprimento às leis e aos princípios éticos que regem as boas práticas empresariais; o estímulo ao desenvolvimento de uma cultura de controles internos; assegurar que a empresa atenda a todos os requisitos dos órgãos reguladores e fiscalizadores.

É sabido que funcionários podem praticar atos em desconformidade com as normas que regulam a atividade da empresa e, com o objetivo de evitar a ocorrência dessas condutas, é interessante para a organização investir na elaboração de um programa de compliance eficiente. Ao estabelecer um programa de conformidade efetivo, a empresa da área de saúde, setor sujeito a um ambiente regulatório bastante rígido, torna-se apta a identificar e mitigar riscos, de forma que considera-se um programa de compliance uma providência adotada para promover a sobrevivência da organização.

Dentre os benefícios que o compliance pode apresentar, é possível mencionar a diminuição de danos à reputação da organização e de seus funcionários. Além disso, um programa de conformidade pode prevenir a cassação da licença operacional da empresa, fator de extrema importância para o setor de saúde. Ademais, o compliance tem o condão de obstar sanções administrativas, pecuniárias e até mesmo criminais, dependendo da situação. Ressalte-se que o programa de cumprimento normativo ainda evita custos não previstos para a empresa, como por exemplo, gastos com processos judiciais.

Trata-se, em suma, de um fator que contribui bastante para que a empresa do setor de saúde se mantenha no mercado a longo prazo. Existe uma tendência no cenário empresarial para modificar o núcleo dos programas de conformidade, de forma que o compliance seja cada vez mais baseado na ética e menos em regras e as empresas do setor de saúde estão reconhecendo a necessidade dessa mudança, passando a incluir a integridade entre os valores das organizações. Essa transição de paradigma vem do fato de o êxito da empresa ser dependente da admiração e da confiança do público, o que repercute na sua reputação e na sua capacidade de atrair clientes, investidores e mesmo funcionários.

O compliance ainda apresenta-se como vantagem competitiva, pois os consumidores estão avaliando a reputação das empresas com mais frequência, buscando não apenas produtos, mas também valores e comprometimento das organizações com práticas íntegras. Para uma empresa do setor de saúde, por exemplo, passar uma imagem de engajamento com princípios éticos é algo particularmente vantajoso, pois os consumidores darão preferência a essas organizações em detrimento de outras envolvidas com situações que envolvam corrupção e fraude.

Sobre a redução e prevenção de fraudes, um programa de cumprimento efetivo contribui de forma significativa para que a empresa não tenha esse tipo de problema, uma vez que cria uma cultura de integridade que diminui a ocorrência dessas situações. A organização que busca criar um ambiente de integridade estabelece um sentimento de colaboração e de pertencimento muito maiores do que as empresas que não se preocupam com a promoção de valores éticos.

Existe uma máxima no cenário empresarial, de acordo com a qual "if you think compliance is expensive try non-compliance". Traduzindo: "se você pensa que compliance é caro, tente não estar em compliance". O custo da não-conformidade é bem mais elevado do que o custo da elaboração e aplicação de um programa de cumprimento normativo, por conta dos prejuízos à reputação da empresa, às sanções pecuniárias e, no que tange ao setor de saúde, o impacto aos pacientes em virtude da interrupção da distribuição de um medicamento.

As empresas que desempenham suas atividades na área de saúde devem estar atentas à importância de se criar um programa de cumprimento para que possam continuar contando com a confiança de seus clientes e, por conseguinte, atuando no mercado de forma consolidada. O compliance ainda é algo relativamente novo em todo o cenário empresarial brasileiro, mas espera-se que o comprometimento com práticas íntegras seja uma postura 
adotada por mais organizações. $\mathrm{O}$ avanço da tecnologia no setor de saúde pode entregar melhores resultados aos consumidores, mas, concomitantemente, a imprecisão sobre as normas que regulam as novas técnicas pode causar dúvidas em relação à conformidade e as empresas que atuam nessa área devem estar preparadas para solucionar tais questionamentos.

\section{Luíza Moura Costa Spínola}

Advogada formada pela Universidade Federal da Bahia. Especialista em Ciências Criminais pela Faculdade Baiana de Direito. Especializada em Compliance pela Legal Ethics Compliance (LEC). Especializada em Crime Organizado, Corrupção e Terrorismo pela Universidade de Salamanca. 